Article

\title{
Effect of Reversal of Conservation Tillage on Soil Nutrient Availability and Crop Nutrient Uptake in Soybean in the Vertisols of Central India
}

\author{
Dharmendra Singh ${ }^{1}$, Sangeeta Lenka ${ }^{1, *} \mathbb{D}$, Narendra Kumar Lenka ${ }^{1}$, Sudhir Kumar Trivedi ${ }^{2}$, \\ Sudeshna Bhattacharjya ${ }^{1} \mathbb{D}$, Sonalika Sahoo ${ }^{3}$, Jayanta Kumar Saha ${ }^{1}$ and Ashok Kumar Patra ${ }^{1} \mathbb{D}$ \\ 1 ICAR-Indian Institute of Soil Science, Nabibagh, Bhopal 462 038, Madhya Pradesh, India; \\ dharamstomar17@gmail.com (D.S.); nklenka@rediffmail.com (N.K.L.); sudeshna.bb@outlook.com (S.B.); \\ jk_saha12000@yahoo.com (J.K.S.); patraak@gmail.com (A.K.P.) \\ 2 Department of Soil Science and Agricultural Chemistry, College of Agriculture, \\ Gwalior 474 001, Madhya Pradesh, India; sudhirtrivedi60@gmail.com \\ 3 ICAR-National Bureau of Soil Survey and Land Use Planning, Amravati Road, \\ Nagpur 440 033, Maharashtra, India; sonalikaiari@yahoo.com \\ * Correspondence: sangeeta_2@rediffmail.com or sangeeta.lenka@icar.gov.in
}

Received: 25 June 2020; Accepted: 7 August 2020; Published: 15 August 2020

check for updates

\begin{abstract}
Effect of conservation tillage on crop performance and soil properties has been studied extensively under different agro-climatic situations. However, the impact of reversal from conservation tillage to conventional tillage on crop growth and soil nutrient release is rarely addressed. Thus, this study was conducted by converting half of the eight years old conservation tillage experiment to the conventional one with a similar level of residue return to compare the effect on soil nutrient availability and nutrient uptake in soybean crops in the Vertisols of Central India. The conservation tillage treatments included no-tillage (NT) and reduced tillage (RT) with 100\% NPK (T1), 100\% NPK + farmyard manure (FYM) at $1.0 \mathrm{Mg}$-carbon (C)/ha (T2), and 100\% NPK + FYM at $2.0 \mathrm{Mg}-\mathrm{C} / \mathrm{ha}$ (T3). After eight years of the experiment, the RT and NT treatments were subjected to conventional tillage, and thus the tillage treatments were RT-CT, RT, NT, and NT-CT. After tillage reversal for three growing seasons, soybean yield and nutrient uptake (N, P, K) got significantly influenced by the tillage and nutrient management. Averaged across nutrient treatments, NT showed highest soil organic carbon (SOC) content $(8.4 \mathrm{~g} / \mathrm{kg})$ in the surface 0-5 cm layer. However, at 5-15 cm depth, the SOC was greater in the RT-CT treatment by $14 \%$ over RT and by $5 \%$ in the NT-CT treatment over NT. The soil nutrient availability $(\mathrm{N}$ and $\mathrm{P})$ was not significantly $(p>0.05)$ affected by the interaction effect of tillage and nutrient on the surface soil layer $(0-5 \mathrm{~cm})$. Interaction effect of tillage and nutrient was significant on available $\mathrm{P}$ content at $5-15 \mathrm{~cm}$ soil depth. In contrast to $\mathrm{N}$, soil available P relatively increased with reversal of tillage in both NT and RT. Tillage reversal (NT-CT, RT-CT) and RT had significantly higher available potassium than NT in $0-5$ and $5-15 \mathrm{~cm}$ soil layers. Among the treatments, NT-CT-T3 showed significantly higher seed N (85.49 kg/ha), P (10.05 kg/ha), and K (24.51 kg/ha) uptake in soybean. The study indicates conventional tillage with residue returns and integrated nutrient management could be a feasible alternative to overcome the limitations of no-till farming in the deep black Vertisols of Central India.
\end{abstract}

Keywords: tillage reversal; nutrient uptake; crop yield; soil properties; nutrient management; soybean; no tillage; reduced tillage; conventional tillage; residue return 


\section{Introduction}

Conservation tillage as a part of the solution to greenhouse gas mitigation and sustainable agriculture started its history to reduce soil erosion, improve soil organic carbon (SOC), and water storage [1-4]. Conservation tillage including no-tillage (NT) and reduced tillage (RT) has a substantial effect on soil properties and processes compared to conventional tillage [5-10]; these changes are beneficial for the delivery of ecosystem services and regulation of climate through carbon sequestration, greenhouse gas fluxes, and energy security [1,4]. Approximately $20 \%$ of the total cultivated area covering a few developed countries like the USA, Brazil, Argentina, Australia, and Canada are presently under conservation agriculture [11]. However, acceptability and spread are limited in developing countries like India [11]. Conservation agriculture, especially no-tillage faces a major challenge of adoption by farmers because of higher weed infestation in the rainy season, lower crop yield in the initial years, increasing soil surface hardness, lack of farm machinery for sowing in heavy residue fields, use of residues for fuel and livestock feed, and lack of skilled manpower [11-13]. Thus, it is difficult to convince farmers of its potential benefits in developing countries like India [14,15]. Although farmers take up no-tillage and reduced tillage with the help of the state agriculture department and national research institutes, they revert to conventional tillage once the efforts of government agencies are withdrawn.

Conservation tillage, especially no-tillage, results in accumulation of crop residues on the soil surface and reduces nutrient distribution in the soil profile [16]. Long-term no-tillage is reported to result in pronounced vertical stratification of soil nutrients, SOC, and other related soil properties [1,3,5,17-20], which is otherwise distributed among soil layers in tilled soils [21]. No-tillage and reduced tillage upon conversion to conventional tillage will have a huge impact on SOC storage, nutrient uptake, and nutrient availability [10]. Further, the stored SOC might be a source of additional $\mathrm{CO}_{2}$ emissions to the atmosphere. The imposition of intensive tillage practices in previously untilled soils may lead to a rapid breakdown of organic matter connected with deterioration in the physical quality of the soils.

Considering the above constraints related to the adoption of no-tillage, a feasible and more convenient option could be conventional tillage with residue retention. Previous research has clearly shown the significance of residue retention for no-tillage to show a better performance than other tillage practices [22,23]. On the other hand, if conventional tillage which is being practiced by the farmers is integrated with residue retention, it might help in enhanced decomposition and mineralization of residues in soil, the release of plant-available nutrients in the soil system, and preventing stratification of SOC and nutrient availability in soil layers. Further, this may help in unlocking the locked nutrients in soil organic matter and may be beneficial in improving soil nutrient availability and crop uptake [24-26]. Tillage operations reduce soil compaction, improve aeration, and create a better environment for soil microorganisms $[27,28]$.

Keeping the above in view, we propose conventional tillage with residue retention as an alternative approach to no-tillage. It was hypothesized that the SOC storage, soil nutrient availability, and crop growth would be better under conventional tillage with residue retention than no-tillage per se. However, there is little information available globally comparing no-tillage with conventional tillage under uniform residue retention in terms of soil properties, crop yield, and nutrient uptake, and more so when no-tillage plots are converted to conventional tillage. Thus, this study was conducted by converting half of the eight years old conservation tillage experiment to the conventional one with a similar level of residue return to compare the effect on SOC storage, soil nutrient availability, and nutrient uptake in soybean crops in the Vertisols of Central India.

The major objectives of the investigation were to assess the changes in (1) soil available nutrients and SOC storage in different soil layers and (2) crop yield upon reversal to conventional tillage from NT and RT practices with uniform residue levels. 


\section{Materials and Methods}

\subsection{Experimental Site}

The study was conducted in an on-going eight-year-old field experiment on conservation tillage established in June 2008 at the research farm of ICAR-Central Institute of Agricultural Engineering, Bhopal, India. The study site is located at $23^{\circ} 15^{\prime} \mathrm{N}$ latitude and $77^{\circ} 25^{\prime} \mathrm{E}$ longitude, at $427 \mathrm{~m}$ above mean sea level, and is characterized by a humid subtropical climate with mild, dry winters and hot summers followed by a humid monsoon season. For other experimental details and initial soil properties of the site, reference is made to Singh et al. [3]. The soil on site was deep Vertisol (Isohyperthermic Typic Haplustert) [29] with clay texture ( $52 \%$ clay), bulk density of $1.34 \mathrm{Mg} / \mathrm{m}^{3}$ at $0.27 \mathrm{~g} / \mathrm{g}$ soil water content, and medium in SOC. The soil was neutral to alkaline in reaction (pH-7.85) with electrical conductivity of $0.3 \mathrm{ds} / \mathrm{m}$ and $\mathrm{Ca}^{2+}$ as the dominant exchangeable cation in the Ap horizon.

\subsection{Experimental Details}

The on-going conservation tillage experiment included no-tillage (NT) and reduced tillage (RT) with $100 \%$ NPK (T1), $100 \%$ NPK + farmyard manure (FYM) at $1.0 \mathrm{Mg}$-carbon (C)/ha (T2), and 100\% $\mathrm{NPK}+\mathrm{FYM}$ at $2.0 \mathrm{Mg}$-C/ha (T3) in a soybean-wheat cropping system. The manure was applied a fortnight before soybean sowing every year. In NT plots there was direct sowing by a no-till-seed cum fertilizer drill and RT plots, one pass rotavator, and sowing by a seed cum fertilizer drill. All the treatments received recommended dose of nutrients for soybean (30:60:30) and wheat (100:60:30) $\mathrm{N}-\mathrm{P}_{2} \mathrm{O}_{5}-\mathrm{K}_{2} \mathrm{O} \mathrm{kg} / \mathrm{ha}$. In the rainy (kharif) season, soybean was sown during the last week of June or first week of July, depending upon the onset of monsoon at a row spacing of $35 \mathrm{~cm}$. Soybean was harvested mostly in the last week of September to the first week of October. In the winter (rabi) season, wheat was sown during the last fortnight of November to the first week of December, depending on the optimum temperature for wheat sowing. Uniformly in all treatments, soybean residues, generated mainly from the leaf fall and above-ground dried stem (30\%) after harvest, were retained on the soil surface. All the recommended crop management practices essential to maintain the crop growth was followed from time to time during the crop growth period. For weed control, glyphosate was applied at least a week before the sowing of soybean and wheat followed by pendimethalin as a pre-emergence spray at 2 days after sowing and use of a suitable post-emergence herbicide for soybean (pursuit/imazethapyr) and wheat $(2,4-\mathrm{D})$ at 20-24 days after sowing. Subsequently, one-hand weeding was done for escaped weeds a week after the post-emergence herbicide spray to keep the fields weed-free. Soybean was grown as a rainfed crop, while wheat was irrigated at critical growth stages. Wheat was sown after the application of pre-sowing irrigation of $6 \mathrm{~cm}$ in depth and three to four post-sowing irrigations depending on the availability of water. The wheat was harvested using a combine harvester, and $30 \%$ above-ground wheat residues were retained in all of the treatments.

To study the effect of tillage reversal at the same level of residue retention on soil properties and crop yield, the RT and NT plots were converted to conventional tillage in the year 2016 after eight years of NT or RT. The RT and NT main plots were divided into two parts each resulting in 4 tillage treatments, viz. (1) RT, (2) RT-CT (reduced tillage converted to conventional tillage), (3) NT, and (4) NT-CT (no-tillage converted to conventional tillage). The residue retention was uniform $(30 \%$ above-ground wheat residue) in all treatments. The RT-CT and NT-CT main plots were ploughed with a cultivator (one pass) at least a week before sowing, rotavator (one pass) followed by sowing with a seed cum fertilizer drill. Therefore, the experimental design was split-plot with three replications. The main plot treatments were tillage at four levels (RT, RT-CT, NT, and NT-CT), and sub-plot treatments were three nutrient levels (100\% NPK (T1), 100\% NPK + FYM at $1.0 \mathrm{Mg}$ C/ha (T2), and 100\% NPK + FYM at $2.0 \mathrm{Mg}-\mathrm{C} / \mathrm{ha}(\mathrm{T} 3))$. 


\subsection{Soil and Crop Yield Sampling and Analysis}

Soil samples (0-5 and 5-15 cm) were randomly collected and homogenized from different treatment plots after the harvest of soybean in the year of 2017. Visible litter and roots were removed before analyzing the soil samples. Part of the soil samples was air-dried at room temperature and gently passed through a $2 \mathrm{~mm}$ sieve and stored in an airtight container for further analysis of soil properties. Standard analytical procedures were followed to analyze the soil samples. The $\mathrm{pH}$ of the soil was determined by using a $\mathrm{pH}$ meter with a glass electrode (model, $420 \mathrm{~A}$ ) using 1:2.5 soil-water suspensions [30]. The soil organic carbon was estimated by the dichromate wet oxidation method of Walkley-Black [31]. In this method, organic matter in the soil was oxidized with a mixture of potassium dichromate $\left(\mathrm{K}_{2} \mathrm{Cr}_{2} \mathrm{O}_{7}\right)$ and concentrated $\mathrm{H}_{2} \mathrm{SO}_{4}$ utilizing the heat of dilution of $\mathrm{H}_{2} \mathrm{SO}_{4}$. Unused $\mathrm{K}_{2} \mathrm{Cr}_{2} \mathrm{O}_{7}$ was back-titrated with ferrous ammonium sulphate. Available nitrogen was estimated by an alkaline $\mathrm{KMnO}_{4}$ method where the organic matter in the soil was oxidized with hot alkaline $\mathrm{KMnO}_{4}$ solution. The ammonia $\left(\mathrm{NH}_{3}\right)$ evolved during oxidation was distilled and trapped in boric acid and mixed indicator solution. The amount of $\mathrm{NH}_{3}$ trapped was estimated by titrating with standard acid [32]. The available phosphorus content of the soil was extracted with $0.5 \mathrm{M} \mathrm{NaHCO}_{3}$ (pH 8.5) [33]. The content of phosphorus in the extract was determined using an ammonium molybdate and ascorbic acid reduction method by developing blue color, and the intensity of the blue color was measured using a spectrophotometer (model-CE2031) at $660 \mathrm{~nm}$ wavelength. Available potassium content in soil was extracted with neutral normal ammonium acetate and the content of potassium in the extract was estimated by a flame photometer (model, CL 378) [30].

Soybean plant samples were collected from an area representing $100 \times 100 \mathrm{~cm}^{2}$ from each treatment after harvestable maturity. In the laboratory, the plant samples were first air-dried, separated into straw and seed, followed by oven drying at $70{ }^{\circ} \mathrm{C}$ until constant weight. The dry weight of seed and straw was recorded after oven drying for $48 \mathrm{~h}$. The dried seed and straw samples were ground in an electric grinder to $0.250 \mathrm{~mm}$ in size. These samples were used for the analysis of $\mathrm{N}, \mathrm{P}$, and $\mathrm{K}$ concentration. Plant N content was determined in Flash 2000 NC elemental analyzer (based on a dry combustion method). Total $\mathrm{P}$ and $\mathrm{K}$ in the tissue were extracted after acid digestion with concentrated nitric acid and perchloric acid (9:4). The total $\mathrm{P}$ concentration in the digested samples was determined by the development of yellow color (ammonium molybdate vanadate mixture) and color intensity was measured in a spectrophotometer (model CE 2031) at $470 \mathrm{~nm}$ after setting the instrument to zero with blank as described by Jackson [30]. The potassium content in the extract was estimated by a flame photometer (ELICO-model CL 378) [34]. The crop nutrient uptake was computed using the following equation:

$$
\text { Nutrient uptake }\left(\mathrm{kg} \mathrm{ha}^{-1}\right)=\frac{\text { Nutrient concentration }(\%) \times \text { Yield }\left(\mathrm{kg} \mathrm{ha}^{-1}\right)}{100}
$$

\subsection{Statistical Analysis}

Data sets were first analyzed for normal distribution and homogeneity of variance using the Shapiro-Wilk and the modified Levene test and then subjected to ANOVA followed by the Tukey's test $(\alpha=0.05)$. All the collected data were analyzed using two-way analysis of variance (ANOVA) using statistical software SPSS 11.5. For a significant $f$-value, the means were separated with least significant difference (LSD) with $p<0.05$.

\section{Results}

\subsection{Soybean Yield and Nutrient Uptake}

The interaction effect of tillage and nutrient was statistically significant $(p<0.05)$ on soybean seed and biomass yield (Figure 1). Among treatments, the effect of the NT-CT-T3 treatment was the highest on seed and biomass yield. The mean soybean seed yield ranged from 845 to $1546 \mathrm{~kg} / \mathrm{ha}$. In general, 
fertilization with NPK+FYM (T2, T3) increased the yield to the extent of 19-35\% over NPK fertilization (T1). The seed yield response to fertilizer followed the order T3 $>\mathrm{T} 2>\mathrm{T} 1$. The soybean total biomass ranged from 2240 to $3405 \mathrm{~kg} / \mathrm{ha}$ across treatments. The tillage and nutrient interaction were significant on N, P, and K uptake by seed, but no consistent pattern was observed on $\mathrm{N}$ uptake (Tables 1-3). For example, the highest $\mathrm{N}$ uptake in straw was observed in the NT-CT-T3 treatment and RT-T3 in the seed. The mean $\mathrm{N}$ uptake (average of all tillage and fertilizer treatments) was $68.5 \mathrm{~kg} / \mathrm{ha}$ in the seed and $25.7 \mathrm{~kg} / \mathrm{ha}$ in the stem of soybean at maturity. Similarly, the mean K uptake followed the order: seed $(18.6 \mathrm{~kg} / \mathrm{ha})>$ straw $(12.3 \mathrm{~kg} / \mathrm{ha})$. Averaged over treatment the P uptake ranged from $7.5 \mathrm{~kg} / \mathrm{ha}$ in seed to $1.5 \mathrm{~kg} / \mathrm{ha}$ in straw. However, the interaction effect was not significant on $\mathrm{P}$ and $\mathrm{K}$ uptake in straw. The main effect of tillage was not significant on N, P, and K uptake in the seed and straw, except for $\mathrm{N}$ uptake in the soybean seed. In general, the reversal of NT to CT relatively increased the nutrient uptake in the seed and straw by approximately $6 \%-10 \%$. Across tillage, the addition of organic manure with NPK fertilizers in the T2 and T3 treatments significantly increased the N uptake by $34 \%$ and $20 \%$ in the seed and straw, respectively, $44 \%$ and $34 \% \mathrm{P}$ uptake in the seed and straw, and $28 \%$ and $24 \% \mathrm{~K}$ uptake in the seed and straw, respectively. The differences in nutrient uptake in the seed and straw were mainly due to differences in biomass and seed yield.

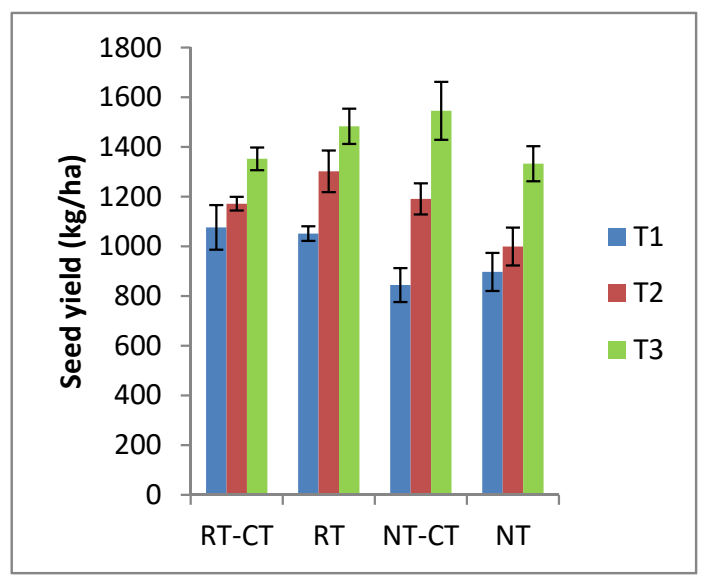

(a)

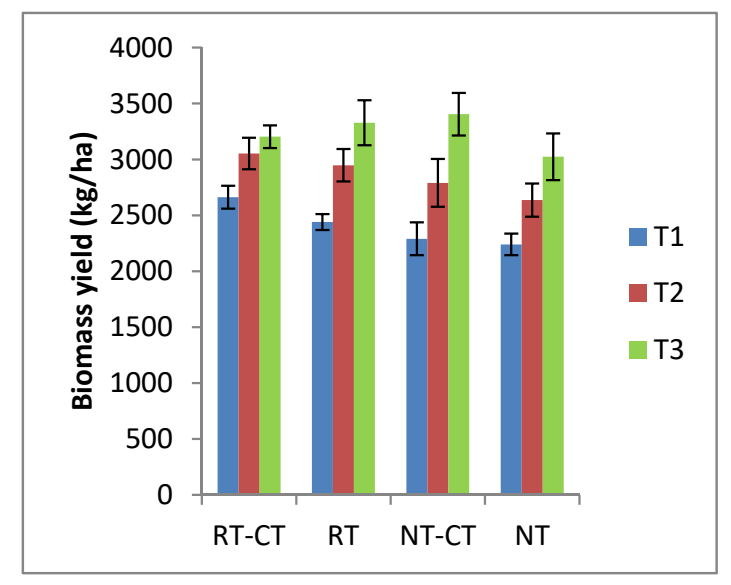

(b)

Figure 1. Effect of tillage, nutrient, and interaction of tillage and nutrient on the seed and biomass yield $(\mathrm{kg} / \mathrm{ha})$ at maturity in soybean in the year of 2017. LSD $(p<0.05)$ to compare the means of treatment for seed: $\mathrm{T}=\mathrm{ns} ; \mathrm{N}=\mathrm{ns} ; \mathrm{TxN}=308$; and straw: $\mathrm{T}=\mathrm{ns} ; \mathrm{N}=\mathrm{ns} ; \mathrm{TxN}=586$. RT: reduced tillage; NT: no-tillage; RT-CT: reduced tillage converted to conventional tillage; NT-CT: no-tillage converted to conventional tillage. (a) seed yield; (b) biomass yield.

\subsection{Soil Properties and Nutrient Availability}

\subsubsection{Soil Organic Carbon}

Significant interaction effect of tillage and nutrient $(\mathrm{TxN})$ was observed on SOC concentration at 0-5 and 5-15 cm soil depth (Table 4). Across tillage and nutrient, the SOC concentration decreased with soil depth from $6.4-9.3 \mathrm{~g} / \mathrm{kg}$ at $0-5 \mathrm{~cm}$ depth to $5.6-8.3 \mathrm{~g} / \mathrm{kg}$ at $5-15 \mathrm{~cm}$ soil depth. Among treatments, SOC was the highest in the NT-T3 treatment at $0-5 \mathrm{~cm}$ and RT-CT-T3 at 5-15 cm soil depth. Compared to T1, the NPK + FYM treatments (T2 and T3) increased the SOC concentration by $25 \%-30 \%$ at $0-5 \mathrm{~cm}$ soil depth and by $11 \%-21 \%$ at $5-15 \mathrm{~cm}$ soil depth. In general, tillage reversal increased SOC concentration at 5-15 cm soil depth. Both RT-CT and NT-CT treatments had relatively higher SOC concentration than the corresponding RT and NT treatments. The increase in SOC was greater in the RT-CT treatment by $14 \%$ over RT and NT-CT treatment by $5 \%$ over NT. Averaged across fertilizer in general, the order of SOC in the $0-5 \mathrm{~cm}$ layer was NT $>\mathrm{NT}-\mathrm{CT} \approx \mathrm{RT} \approx \mathrm{RT}-\mathrm{CT}$. 
Table 1. Effect of tillage, nutrient, and interaction of tillage and nutrient on $\mathrm{N}$ uptake (kg/ha) in soybean at maturity in the year of 2107 with statistical significance ( $p$ values) and LSD $(p<0.05)$ to compare the means of treatment.

\begin{tabular}{ccccc}
\hline & T1 & T2 & T3 & MEAN \\
\hline RT-CT & 63.15 & Seed & & \\
RT & 60.15 & 68.85 & 79.44 & 70.48 \\
NT-CT & 49.72 & 72.63 & 90.11 & 74.29 \\
NT & 49.78 & 66.24 & 85.49 & 67.15 \\
MEAN & 55.70 & 62.25 & 74.28 & 62.10 \\
& TILLAGE & NUTRIENT & INTERACTION (TxN) \\
LSD $(p<0.05)$ & 5.84 & 10.08 & 6.41 & \\
$p$ Value & 0.041 & 0.019 & 0.041 & \\
& & Straw & & \\
RT-CT & 26.91 & 25.08 & 28.49 & 26.83 \\
RT & 24.95 & 28.35 & 24.34 & 25.88 \\
NT-CT & 18.61 & 26.10 & 32.84 & 25.85 \\
NT & 20.61 & 23.52 & 29.07 & 24.40 \\
MEAN & 22.77 & 25.76 & 28.68 & \\
& TILLAGE & NUTRIENT & INTERACTION (TxN) \\
LSD $(p<0.05)$ & NS & NS & 7.64 & \\
P Value & 0.737 & 0.245 & 0.042 & \\
\hline
\end{tabular}

T1: $100 \%$ NPK; T2: 100\% NPK + farmyard manure (FYM) at 1.0 Mg-C/ha; T3: 100\% NPK + FYM at 2.0 Mg-C/ha (T3).

Table 2. Effect of tillage, nutrient, and the interaction of tillage and nutrient on $\mathrm{P}$ uptake $(\mathrm{kg} / \mathrm{ha})$ in soybean at maturity in the year of 2017 with statistical significance ( $p$ values) and LSD $(p<0.05)$ to compare the means of treatment.

\begin{tabular}{|c|c|c|c|c|}
\hline & T1 & T2 & T3 & MEAN \\
\hline \multicolumn{5}{|c|}{ Seed } \\
\hline RT-CT & 6.08 & 7.41 & 8.86 & 7.45 \\
\hline RT & 6.04 & 8.23 & 9.58 & 7.95 \\
\hline NT-CT & 5.28 & 7.64 & 10.05 & 7.65 \\
\hline NT & 5.77 & 6.40 & 8.65 & 6.94 \\
\hline \multirow[t]{2}{*}{ MEAN } & 5.79 & 7.42 & 9.29 & \\
\hline & TILLAGE & NUTRIENT & \multicolumn{2}{|c|}{ INTERACTION (TxN) } \\
\hline $\operatorname{LSD}(p<0.05)$ & NS & 1.52 & \multicolumn{2}{|c|}{2.01} \\
\hline$p$ Value & 0.703 & 0.609 & \multicolumn{2}{|l|}{0.0147} \\
\hline \multicolumn{5}{|c|}{ Straw } \\
\hline RT-CT & 2.84 & 3.25 & 3.68 & 3.26 \\
\hline RT & 3.02 & 3.14 & 4.42 & 3.53 \\
\hline NT-CT & 1.85 & 2.17 & 3.40 & 2.47 \\
\hline NT & 1.93 & 2.97 & 2.88 & 2.59 \\
\hline \multirow[t]{2}{*}{ MEAN } & 2.41 & 2.88 & 3.59 & \\
\hline & TILLAGE & NUTRIENT & \multicolumn{2}{|c|}{ INTERACTION (TxN) } \\
\hline $\operatorname{LSD}(p<0.05)$ & NS & NS & NS & \\
\hline$p$ Value & 0.235 & 0.218 & 0.358 & \\
\hline
\end{tabular}

T1: $100 \%$ NPK; T2: 100\% NPK + farmyard manure (FYM) at 1.0 Mg-C/ha; T3: 100\% NPK + FYM at 2.0 Mg-C/ha (T3). 
Table 3. Effect of tillage, nutrient, and the interaction of tillage and nutrient on $\mathrm{K}$ uptake (kg/ha) in soybean at maturity in the year of 2017 with statistical significance ( $p$ values) and LSD $(p<0.05)$ to compare the means of treatment.

\begin{tabular}{ccccc}
\hline & T1 & T2 & T3 & MEAN \\
\hline RT-CT & 16.74 & Seed & & \\
RT & 17.64 & 17.52 & 21.15 & 18.47 \\
NT-CT & 13.53 & 21.15 & 22.79 & 20.53 \\
NT & 14.71 & 18.92 & 24.51 & 18.99 \\
MEAN & 15.66 & 14.64 & 19.54 & 16.30 \\
& TILLAGE & NUTRIENT & INTERACTION (TxN) \\
LSD $(p<0.05)$ & NS & 2.91 & 5.16 & \\
$p$ Value & 0.659 & 0.032 & 0.045 & \\
& & Straw & & \\
RT-CT & 12.3 & 12.7 & 14.0 & 13.01 \\
RT & 12.1 & 11.9 & 16.8 & 13.60 \\
NT-CT & 8.4 & 10.2 & 15.2 & 11.25 \\
NT & 9.6 & 12.5 & 11.8 & 11.32 \\
MEAN & 10.60 & 11.84 & 14.45 & \\
& TILLAGE & NUTRIENT & INTERACTION (TxN) \\
LSD $(p<0.05)$ & NS & NS & NS & \\
$p$ Value & 0.348 & 0.549 & 0.199 & \\
\hline
\end{tabular}

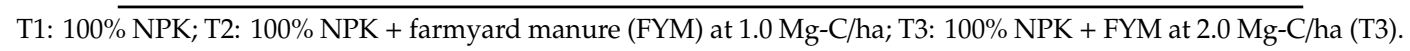

Table 4. Effect of tillage, nutrient, and the interaction of tillage and nutrient on SOC $(\mathrm{g} / \mathrm{kg})$ after the harvest of soybean in the year of 2017 with statistical significance ( $p$ values) and LSD $(p<0.05)$ to compare the means of treatment.

\begin{tabular}{ccccc}
\hline & T1 & T2 & T3 & MEAN \\
\hline RT-CT & 6.6 & $0-5 \mathrm{~cm}$ & & \\
RT & 6.4 & 8.0 & 8.5 & 7.7 \\
NT-CT & 6.6 & 8.4 & 8.7 & 7.8 \\
NT & 7.2 & 8.3 & 8.7 & 7.9 \\
MEAN & 6.7 & 8.7 & 9.3 & 8.4 \\
& TILLAGE & NUTRIENT & INTERACTION (TxN) \\
LSD $(p<0.05)$ & NS & 1.5 & 1.7 & \\
$p$ Value & 0.061 & 0.001 & 0.038 & \\
& & $5-15 \mathrm{~cm}$ & & \\
RT-CT & 6.9 & 7.5 & 8.3 & 7.5 \\
RT & 5.6 & 6.6 & 7.5 & 6.6 \\
NT-CT & 6.4 & 7.0 & 8.0 & 7.1 \\
NT & 6.4 & 6.8 & 7.2 & 6.8 \\
MEAN & 6.3 & 7.0 & 7.8 & \\
& TILLAGE & NUTRIENT & INTERACTION (TxN) \\
LSD $(p<0.05)$ & NS & 1.01 & 1.1 & \\
$p$ Value & 0.09 & 0.001 & 0.041 &
\end{tabular}

T1: $100 \%$ NPK; T2: $100 \%$ NPK + farmyard manure (FYM) at 1.0 Mg-C/ha; T3: $100 \%$ NPK + FYM at 2.0 Mg-C/ha (T3).

\subsubsection{Soil Nutrient Availability}

In general, the main effects of tillage and fertilizer were significant on available $\mathrm{N}, \mathrm{P}$, and $\mathrm{K}$. However, the interaction effect was not significant on available $\mathrm{N}$ and $\mathrm{K}$ in $0-5$ and $5-15 \mathrm{~cm}$ soil layers (Tables 5-7). Similarly, no significant effect of tillage was observed on available $\mathrm{N}$ and $\mathrm{P}$ at the $0-5 \mathrm{~cm}$ soil layer and $\mathrm{K}$ at $5-15 \mathrm{~cm}$. The soil available $\mathrm{N}$ was relatively higher under NT and RT compared to the NT-CT and RT-CT treatments in both soil layers. Averaged over treatments the mean soil available $\mathrm{N}$ ranged from $341 \mathrm{~kg} / \mathrm{ha}$ in $0-5 \mathrm{~cm}$ to $293 \mathrm{~kg} / \mathrm{ha}$ in $5-15 \mathrm{~cm}$ soil depth. The interaction effect of 
tillage and fertilizer was significant on soil available $P$ at the $5-15 \mathrm{~cm}$ soil layer only. The reversal in tillage (RT-CT and NT-CT) along with the application of 100\% NPK + FYM (T3) resulted in higher soil available P than the NT and RT treatment with $100 \%$ NPK (T1). Averaged across tillage and nutrient, the mean soil available P ranged from $30 \mathrm{~kg} / \mathrm{ha}$ in $0-5 \mathrm{~cm}$ to $12 \mathrm{~kg} / \mathrm{ha}$ in $5-15 \mathrm{~cm}$ soil depth. Unlike $\mathrm{N}$ and P, tillage reversal NT-CT had a significant effect on soil available K compared to NT in the $0-5 \mathrm{~cm}$ soil layer (Table 7). Although tillage reversal (NT-CT and RT-CT) tended to have higher soil available K in the $5-15 \mathrm{~cm}$ soil layer, the effect was not significant. Averaged across tillage and nutrient, the mean soil available $\mathrm{K}$ ranged from $679 \mathrm{~kg} / \mathrm{ha}$ in $0-5 \mathrm{~cm}$ to $525 \mathrm{~kg} / \mathrm{ha}$ in $5-15 \mathrm{~cm}$ soil depth.

Table 5. Effect of tillage, nutrient, and the interaction of tillage and nutrient on soil available $\mathrm{N}(\mathrm{kg} / \mathrm{ha})$ after the harvest of soybean in the year of 2017 with statistical significance ( $p$ values) and LSD $(p<0.05)$ to compare the means of treatment.

\begin{tabular}{ccccc}
\hline & T1 & T2 & T3 & MEAN \\
\hline RT-CT & 326 & $0-5 \mathrm{~cm}$ & & 332 \\
RT & 314 & 320 & 350 & 329 \\
NT-CT & 332 & 318 & 354 & 339 \\
NT & 333 & 341 & 344 & 364 \\
MEAN & 326 & 368 & 392 & \\
& TILLAGE & NUTRIENT & INTERACTION (TxN) \\
LSD $(p<0.05)$ & NS & 26 & NS & \\
$p$ Value & 0.091 & 0.039 & 0.806 & \\
RT-CT & 259 & $5-15 \mathrm{~cm}$ & & 283 \\
RT & 269 & 292 & 298 & 281 \\
NT-CT & 266 & 274 & 301 & 312 \\
NT & 305 & 299 & 327 & \\
MEAN & 275 & 308 & 323 & 312 \\
LSD $(p<0.05)$ & TILLAGE & NUTRIENT & INTERACTION (TxN) \\
$p$ Value & 21 & 18 & NS & \\
\hline N & 0.017 & 0.001 & 0.605 &
\end{tabular}

T1: $100 \%$ NPK; T2: 100\% NPK + farmyard manure (FYM) at 1.0 Mg-C/ha; T3: 100\% NPK + FYM at 2.0 Mg-C/ha (T3).

Table 6. Effect of tillage, nutrient, and the interaction of tillage and nutrient on soil available P (kg/ha) after the harvest of soybean in the year of 2017. Statistical significance ( $p$ values) and LSD $(p<0.05)$ to compare the means of treatment.

\begin{tabular}{ccccc}
\hline & T1 & T2 & T3 & MEAN \\
\hline & & $0-5 \mathrm{~cm}$ & & \\
RT-CT & 23 & 28 & 43 & 31 \\
RT & 22 & 30 & 36 & 29 \\
NT-CT & 27 & 28 & 36 & 30 \\
NT & 25 & 27 & 35 & 29 \\
MEAN & 24 & 28 & 38 & \\
LSD $(p<0.05)$ & TILLAGE & NUTRIENT & INTERACTION (TxN) \\
$p$ Value & NS & 3 & NS & \\
RT-CT & 0.355 & 0.001 & 0.118 & \\
RT & 7 & $5-15 \mathrm{~cm}$ & & 12 \\
NT-CT & 8 & 13 & 17 & 11 \\
NT & 10 & 9 & 15 & 13 \\
MEAN & 11 & 12 & 17 & 12 \\
& 9 & 12 & 15 & \\
LSD $(p<0.05)$ & TILLAGE & NUTRIENT & INTERACTION (TxN) \\
$p$ Value & 0.476 & 2 & 4 & \\
\hline
\end{tabular}


Table 7. Effect of tillage, nutrient, and the interaction of tillage and nutrient on soil available $\mathrm{K}(\mathrm{kg} / \mathrm{ha})$ after the harvest of soybean in the year of 2017. Statistical significance ( $p$ values) and LSD $(p<0.05)$ to compare the means of treatment.

\begin{tabular}{ccccc}
\hline & T1 & T2 & T3 & MEAN \\
\hline RT-CT & 622 & $0-5 \mathrm{~cm}$ & & \\
RT & 635 & 720 & 724 & 689 \\
NT-CT & 645 & 678 & 706 & 673 \\
NT & 609 & 710 & 750 & 701 \\
MEAN & 628 & 654 & 695 & 653 \\
& TILLAGE & NUTRIENT & INTERACTION (TxN) \\
LSD $(p<0.05)$ & 30 & 37 & NS & \\
P Value & 0.023 & 0.001 & 0.960 & \\
& 466 & $5-15 \mathrm{~cm}$ & & \\
RT-CT & 487 & 580 & 645 & 564 \\
RT & 488 & 489 & 573 & 516 \\
NT-CT & 482 & 522 & 574 & 528 \\
NT & 481 & 493 & 501 & 492 \\
MEAN & TILLAGE & NUTRIENT & INTERACTION (TxN) \\
& NS & 35 & NS & \\
LSD $(p<0.05)$ & 0.171 & 0.001 & 0.063 & \\
$p$ Value & 521 & 573 & \\
\hline
\end{tabular}

T1: $100 \%$ NPK; T2: 100\% NPK + farmyard manure (FYM) at 1.0 Mg-C/ha; T3: 100\% NPK + FYM at 2.0 Mg-C/ha (T3).

\subsubsection{Soil Reaction}

The effect of tillage and nutrient management was not significant on soil $\mathrm{pH}_{(\mathrm{H} 2 \mathrm{O})}$. Soil $\mathrm{pH}_{(\mathrm{H} 2 \mathrm{O})}$ under NT was 0.06-0.2 units lower than under RT at a depth of 0-5 $\mathrm{cm}$ but was not different between tillage regimes at $5-15 \mathrm{~cm}$ soil depth (Table 8). Addition of FYM at $2 \mathrm{Mg}-\mathrm{C} /$ ha with $100 \%$ NPK lowered the soil $\mathrm{pH}_{(\mathrm{H} 2 \mathrm{O})}$ by 0.05 units compared to $100 \%$ NPK.

Table 8. Effect of tillage, nutrient, and the interaction of tillage and nutrient on soil $\mathrm{pH}_{(\mathrm{H} 2 \mathrm{O})}$ after the harvest of soybean in the year of 2017. Statistical significance ( $p$ values) and LSD $(p<0.05)$ to compare the means of treatment.

\begin{tabular}{ccccc}
\hline & T1 & T2 & T3 & MEAN \\
\hline & & $0-5 \mathrm{~cm}$ & & \\
RT-CT & 7.94 & 7.95 & 7.79 & 7.89 \\
RT & 7.88 & 7.96 & 7.85 & 7.90 \\
NT-CT & 7.83 & 7.78 & 7.87 & 7.83 \\
NT & 7.75 & 7.69 & 7.67 & 7.70 \\
MEAN & 7.85 & 7.85 & 7.80 & \\
& TILLAGE & NUTRIENT & INTERACTION (TxN) \\
LSD $(p<0.05)$ & NS & NS & NS & \\
$p$ Value & 0.396 & 0.317 & 0.062 & \\
& & $5-15 \mathrm{~cm}$ & & \\
RT-CT & 7.89 & 7.87 & 7.84 & 7.87 \\
RT & 7.91 & 7.98 & 7.81 & 7.90 \\
NT-CT & 7.90 & 7.90 & 7.88 & 7.89 \\
NT & 7.91 & 7.94 & 7.86 & 7.91 \\
MEAN & 7.90 & 7.92 & 7.85 & \\
& TILLAGE & NUTRIENT & INTERACTION (TxN) \\
LSD $(p<0.05)$ & NS & NS & NS & \\
$p$ Value & 0.723 & 0.093 & 0.940 & \\
\hline
\end{tabular}




\section{Discussion}

\subsection{Soybean Yield and Nutrient Uptake}

The likely significant $(p<0.05)$ interaction effect of tillage and fertilization on the soybean seed and biomass yield at maturity was probably due to the influence of tillage operations on soil properties, nutrient release, and availability from the soil and fertilizer [8,35,36]. Reversal of NT and RT to CT at the same level of residue showed a positive effect on the soybean yield. This could be because of the improvement of nutrient availability and uptake due to tillage $[19,36]$. Better growth and yield performance of the soybean observed under complementary use of NPK + FYM compared with the NPK fertilizer alone could be attributed to increased nutrient uptake and nutrient use efficiency, following the application of the organic manure [37-40]. Agbede [41] reported that nutrients from mineral fertilizers enhanced the establishment of crops, while those from the mineralization of organic manure promoted yield when both fertilizers were combined. The reversal of NT to CT with NPK + FYM had a significant effect on $\mathrm{N}$ uptake. This could be attributed to enhanced mineralization of crop residue accumulated at the soil surface in the NT treatment from tillage which in turn increased crop nutrient availability and uptake. Similar results were obtained by [10] who observed greater nutrient uptake (N, P) and crop yield after four years of reversal of NT to reduced tillage. Better utilization of nutrients by crops because of more root biomass and proliferation in the NT-CT treatment might have resulted in greater $\mathrm{N}, \mathrm{P}$, and $\mathrm{K}$ uptake. However, we did not observe higher $\mathrm{N}$ uptake in the RT-CT treatment than RT. Our results are in agreement with Ishaq [6] who observed no significant difference among conventional tillage, minimum tillage, and deep tillage on the nutrient uptake by wheat. Irrespective of tillage system, the addition of FYM with $100 \%$ NPK resulted in higher nutrient uptake because FYM has a lower C:N ratio than crop residue that acts as a better substrate for greater microbial activity and related soil enzymatic activity for enhanced soil organic matter mineralization. Secondly, the application of FYM with NPK fertilizer was effective in increasing SOC concentration and soil nutrient availability (Tables 5-7). Several studies reported a positive effect of organic manure application on crop yield, biomass, nutrient uptake, and soil health [39-42].

\subsection{Soil Properties and Nutrient Availability}

Higher SOC in the surface $0-5 \mathrm{~cm}$ soil layer observed in our study is in conformity with previous studies which showed surface-layer $(0-5 \mathrm{~cm})$ increments of SOC content in NT than RT $[8,28,43,44]$. The increase in SOC concentration with reversal of tillage was closely associated with enhanced decomposition of incorporated crop residues. The mixing of crop residue with tillage improves soil aeration and microbial activity that increases the mineralization of soil organic material [45-49]. Further, greater input of $\mathrm{C}$ and $\mathrm{N}$ through above- and below-ground biomass and FYM in the NT-CT-T3 and RT-CT-T3 treatment would have resulted in higher SOC concentration compared to other treatments. Lal [50] also reported the application of inorganic fertilizer in conjunction with organic manure increasing SOC and crop yield. The volume and density of root proliferation and biomass could be greater at the 5-15 cm soil layer than 0-5 cm which might have contributed to no significant effect of tillage on soil nutrient content $(\mathrm{N}$ and $\mathrm{K})$ at the $0-5 \mathrm{~cm}$ layer [5]. After three growing periods, tillage reversal (NT-CT and RT-CT) significantly lowered soil available $\mathrm{N}$ in the 5-15 cm soil layer which could be attributed to higher crop biomass and $\mathrm{N}$ uptake by soybean. The amount of residue incorporation is greater as tillage intensity increases in the NT-CT and RT-CT treatments. Tillage enhances the decomposition and mineralization of incorporated crop residues by increasing soil aeration [51] and soil microbial activity [52]. Further, mineralization of residue is strongly related to soil nutrient availability and crop nutrient uptake. Greater soil available N in NT than NT-CT was ascribed to higher crop biomass and N uptake in the NT-CT treatment that could have lowered soil available $\mathrm{N}$ in NT-CT.

Interaction effect of tillage and nutrient was found significant on available P content at the 5-15 $\mathrm{cm}$ soil depth. In contrast to N, soil available P relatively increased with the reversal of tillage in NT 
and RT. This could be attributed to the accumulation of inorganic P derived from the incorporation and mineralization of organic residues in reverse tillage treatments [53] and to the effect of organic manure (FYM) negative charges maintaining freely available phosphate [54]. Other researchers have observed similar effects of tillage and nutrient management on available P surface layer soil [55-57]. In comparing the tillage systems, tillage reversal (NT-CT, RT-CT) and RT had significantly higher available potassium than NT. Other studies have also reported similar effects of tillage and organic manure application on available $\mathrm{K}$ in soil $[58,59]$. This result was explained by the mineralization of this element resulting from mechanical incorporation and mineralization of crop residues, fertilizers, and FYM in the NT-CT, RT-CT, and RT treatments and agree with those reported by $[60,61]$.

Addition of organic manure in the T2 and T3 treatments significantly increased the N, P, and $\mathrm{K}$ content by $3 \%-13 \%, 17 \%-67 \%$, and $8 \%-19 \%$, respectively, over T1 (100\% NPK) across tillage and soil depth. Other previous studies suggested that integrated use of NPK + FYM can maintain a high level of crop production and soil nutrients throughout the period of the experiment $[1,2,8]$ because FYM ensures the sustained activity of microorganisms and the regular dynamics of labile biomass carbon [62]. The higher availability of potassium in the NPK + FYM treatments may be attributed to the beneficial effect of organic manures on the reduction of potassium fixation and release of potassium due to interaction of organic with clay $[63,64]$.

A similar effect of no-tillage was reported for the $0-5 \mathrm{~cm}$ soil layer due to enhancement of acidification $[7,21,64]$. However, among the tillage practices, the mean highest $\mathrm{pH}$ was found under RT-CT and RT (7.90) followed by NT-CT (7.83) and the lowest under NT (7.70) in the $0-5 \mathrm{~cm}$ soil layer. And the order for the 5-15 cm soil layer was RT $\approx N T>N T-C T>R T-C T$. Tarkalson [63] reported a 9 per cent decrease in soil $\mathrm{pH}$ under NT as compared to $\mathrm{CT}$ due to enhancement of acidification. Across tillage, soil $\mathrm{pH}$ was found to relatively decrease with application of FYM at $2.0 \mathrm{Mg}-\mathrm{C} / \mathrm{ha}$ (T3) at $0-5$ and $5-15 \mathrm{~cm}$.

\section{Conclusions}

In conclusion, the study indicated that under comparable residue retention, conventional tillage can perform better in terms of crop performance and SOC storage than no-tillage. The findings are particularly vital in the context of poor adoption of no-tillage due to several constraints, such as high weed infestation, difficulty in seeding, and others, under no-tillage conditions. Thus, the alternative approach of conventional tillage with similar residue retention as under no-tillage could be a better strategy in improving SOC storage, crop performance, and overall soil sustainability. The results further showing that integrated nutrient management increasing the seed yield of soybean indicate the role of organic manures in maintaining soil productivity across different types of tillage. Tillage reversal showed a beneficial effect on crop yield and nutrient uptake in the NT-CT treatment with the application of $100 \% \mathrm{NPK}+\mathrm{FYM}$ at $2.0 \mathrm{Mg}-\mathrm{C} / \mathrm{ha}$. The magnitude of nutrient uptake was not consistently influenced by tillage treatments, but the application of organic manure relatively increased the nutrient uptake. Tillage reversal from the RT-CT and NT-CT treatments under uniform residue retention had no negative effect on soil properties. However, the addition of organic manure with inorganic fertilizer significantly increased the SOC and the related nutrient availability in all tillage treatments. The finding suggests that returning crop residue and conventional tillage with integrated nutrient management could be a viable approach to resolve the issue of non-adoption of no-tillage in different cropping systems, particularly in developing countries. Conventional or minimum tillage with residue retention may increase the potential for soil productivity and offset the limitations of no-till farming in different cropping systems and soil types. This particular approach can be particularly useful for developing countries characterized by small landholding situations and farmers' hesitation in switching to no-tillage. Nevertheless, future research is required to understand the comparative performance of the proposed approach over no-tillage under different crop, soil, and climatic conditions. 
Author Contributions: Conceptualization, S.L., N.K.L., and D.S.; methodology, S.L., D.S., S.B., and N.K.L.; software, S.L., S.K.T., and D.S.; formal analysis, S.L., S.K.T., S.B., S.S., and D.S.; investigation, S.L. and D.S.; resources, S.L. and J.K.S.; writing—original draft preparation, S.L. and D.S.; writing-review and editing, S.L., N.K.L., S.B., S.S., J.K.S., and A.K.P.; visualization, S.L., S.S., and D.S.; supervision, S.L. and A.K.P.; project administration, S.L. and A.K.P. All authors have read and agreed to the published version of the manuscript.

Funding: This research received no external funding.

Acknowledgments: The support extended by ICAR-Central Institute of Agricultural Engineering (ICAR-CIAE) and ICAR-Indian Institute of Soil Science (ICAR-IISS) in carrying out the study is duly acknowledged. Thanks to Ravinder Singh, Farm Manager, ICAR-CIAE, for timely help in farm operations. We also thank anonymous reviewers and the editor for their useful and constructive comments. The authors are grateful to New India Publishing Agency (NIPA) www.nipabooks.com, New Delhi, India, for partially funding the article processing charges of the manuscript.

Conflicts of Interest: The authors declare no conflict of interest.

\section{References}

1. Lenka, S.; Lenka, N.K. Conservation Tillage for Climate Change Mitigation-The Reality. Clim. Chang. Environ. Sustain. 2014, 2, 1. [CrossRef]

2. Lenka, S.; Lenka, N.K.; Singh, R.C.; Subba Rao, A.; Kundu, S.; Raghuwansi, J.; Patidar, C.P. Greenhouse gas emission and soil properties as influenced by wheat biomass burning in Vertisols of central India. Curr. Sci. 2014, 107, 1050-1154.

3. Singh, R.C.; Lenka, S.; Singh, C.D. Conservation tillage and manure effect on soil aggregation, yield and energy requirement for wheat (Triticum aestivum) in vertisols. Indian J. Agric. Sci. 2014, 84, 267-271.

4. Lal, R.; Kimble, J.M. Conservation tillage for carbon sequestration. Nutr. Cycl. Agroecosyst 1997, 49, $243-253$. [CrossRef]

5. Franzluebbers, A.J.; Hons, F.M. Soil-profile distribution of primary and secondary plant-available nutrients under conventional and no tillage. Soil Tillage Res. 1996. [CrossRef]

6. Ishaq, M.; Ibrahim, M.; Lal, R. Tillage effect on nutrient uptake by wheat and cotton as influenced by fertilizer rate. Soil Tillage Res. 2001, 62, 41-53. [CrossRef]

7. Mrabet, R.; Ibno-Namr, K.; Bessam, F.; Saber, N. Soil chemical quality changes and implications for fertilizer management after 11 years of no-tillage wheat production systems in Semiarid Morocco. Land Degrad. Dev. 2001, 12, 505-517. [CrossRef]

8. Malhi, S.S.; Lemke, R.; Wang, Z.; Chhabra, B.S. Tillage, nitrogen and crop residue effects on crop yield, nutrient uptake, soil quality, and greenhouse gas emissions. Soil Tillage Res. 2006, 90, 171-183. [CrossRef]

9. Halpern, M.T. Tillage and Residue Management Effects on Soil Organic Matter Dynamics in a Sandy-Loam; McGill University: Montréal, QC, Canada, 2009.

10. Dyck, M.; Malhi, S.S.; Nyborg, M.; Puurveen, D. Effects of Short-term Tillage of a Long-term No-Till Land on Crop Yield and Nutrient Uptake in Two Contrasting Soil Types. Sustain. Agric. Res. 2016, 5, 32. [CrossRef]

11. Bhan, S.; Behera, U.K. Conservation agriculture in India - Problems, prospects and policy issues. Int. Soil Water Conserv. Res. 2014, 2, 1-12. [CrossRef]

12. Buah, S.S.J.; Ibrahim, H.; Derigubah, M.; Kuzie, M.; Segtaa, J.V.; Bayala, J.; Zougmore, R.; Ouedraogo, M. Tillage and fertilizer effect on maize and soybean yields in the Guinea savanna zone of Ghana. Agric. Food Secur. 2017, 6, 1-11. [CrossRef]

13. Derpsch, R.; Friedrich, T. Global Overview of Conservation Agriculture Adoption. In Proceedings of the World Congress on Conservation Agriculture, New Delhi, India, 4-7 February 2009.

14. Giller, K.E.; Andersson, J.A.; Corbeels, M.; Kirkegaard, J.; Mortensen, D.; Erenstein, O.; Vanlauwe, B. Beyond conservation agriculture. Front. Plant Sci. 2015, 6. [CrossRef] [PubMed]

15. Vasanthakumar, J.; Ramasubramaniyan, M.; Hansra, B.S. Constraints to Adoption of Conservation Agriculture Technologies among the Farming Community in Tamil Nadu, India. Int. J. Curr. Microbiol. Appl. Sci. 2017, 6, 988-992. [CrossRef]

16. Jakab, G.; Madarász, B.; Szabó, J.A.; Tóth, A.; Zacháry, D.; Szalai, Z.; Kertész, Á.; Dyson, J. Infiltration and soil loss changes during the growing season under ploughing and conservation tillage. Sustainability 2017, 9, 1726. [CrossRef] 
17. Lupwayi, N.Z.; Clayton, G.W.; O 'donovan, J.T.; Harker, K.N.; Turkington, T.K.; Soon, Y.K.; 'donovan, O.; Harker, J.T. Soil nutrient stratification and uptake by wheat after seven years of conventional and zero tillage in the Northern Grain belt of Canada. Can. J. Soil Sci. 2006, 86, 767-778. [CrossRef]

18. Moreno, F.; Murillo, J.M.; Pelegrín, F.; Girón, I.F. Long-term impact of conservation tillage on stratification ratio of soil organic carbon and loss of total and active $\mathrm{CaCO}_{3}$. Soil Tillage Res. 2006, 85, 86-93. [CrossRef]

19. Hati, K.M.; Chaudhary, R.S.; Mandal, K.G.; Bandyopadhyay, K.K.; Singh, R.K.; Sinha, N.K.; Mohanty, M.; Somasundaram, J.; Saha, R. Effects of Tillage, Residue and Fertilizer Nitrogen on Crop Yields, and Soil Physical Properties Under Soybean-Wheat Rotation in Vertisols of Central India. Agric. Res. 2015, 4, 48-56. [CrossRef]

20. Wang, H.; Wang, S.; Zhang, Y.; Wang, X.; Wang, R.; Li, J. Tillage system change affects soil organic carbon storage and benefits land restoration on loess soil in North China. L. Degrad. Dev. 2018, 1-8. [CrossRef]

21. Samarendra, H.; Robert, P.; Roland, B.; Liz, D.; Peter, R.; Sarah, D.; Debbie, A. Effect of tillage system and straw management on organic matter dynamics. Agron. Sustain. Dev. 2009, 29, 525-533.

22. Sharma, S.; Thind, H.S.; Yadvinder-Singh; Sidhu, H.S.; Jat, M.L.; Parihar, C.M. Effects of crop residue retention on soil carbon pools after 6 years of rice-wheat cropping system. Environ. Earth Sci. 2019, 78, 1-14. [CrossRef]

23. Lu, X. A meta-analysis of the effects of crop residue return on crop yields and water use efficiency. PLoS ONE 2020, 15, e231740. [CrossRef] [PubMed]

24. Meena, J.R.; Behera, U.K.; Chakraborty, D.; Sharma, A.R. Tillage and residue management effect on soil properties, crop performance and energy relations in greengram (Vigna radiata L.) under maize-based cropping systems. Int. Soil Water Conserv. Res. 2015, 3, 261-272. [CrossRef]

25. Usman, K.; Khan, E.A.; Khan, N.; Rashid, A.; Yazdan, F.; Ud Din, S. Response of wheat to tillage plus rice residue and nitrogen management in rice-wheat system. J. Integr. Agric. 2014, 13, 2389-2398. [CrossRef]

26. Dick, W.A. Organic Carbon, Nitrogen, and Phosphorus Concentrations and pH in Soil Profiles as Affected by Tillage Intensity1. Soil Sci. Soc. Am. J. 1983, 47, 102. [CrossRef]

27. Lenka, S.; Lenka, N.K.; Singh, R.K.; Singh, R.C.; Hati, K.M.; Lakaria, B.L.; Raghuwanshi, J. Impact of Conservation Tillage on Soil Aggregation, Cracking and Bypass Flow in Vertisols of Central India. J. Indian Soc. Soil Sci. 2014, 62, 189-196.

28. Lenka, S.; Lenka, N.K.; Singh, R.C.; Manna, M.C.; Misra, A.K.; Rautaray, S.K. Tillage and Manure Induced Changes in Carbon Storage and Carbon Management Index in Soybean-Wheat Cropping System in the Vertisols of Central India. Natl. Acad. Sci. Lett. 2015, 38, 461-464. [CrossRef]

29. FAO. World Reference Base for Soil Resources 2014. International Soil Classification System for Naming Soils and Creating Legends for Soil Maps; FAO: Rome, Italy, 2014; ISBN 9789251083697.

30. Jackson, M. Soil Chemical Analysis; Pentice hall of india Pvt Ltd.: New Delhi, India, 1973.

31. Schnitzer, M. Total carbon, organic matter, and carbon. In Methods of Soil Analysis. Part 2; Page, A.L., Miller, R.H., Keeney, D.R., Eds.; American Society of Agronomy: Madison, WI, USA, 1982; Volume 9 , pp. 539-577.

32. Subbaiah, V.; Asija, G. A rapid procedure for utilization of available nitrogen in soil. Curr. Sci. 1956, 26, 258-260.

33. Olsen, S.R.; Cole, C.V.; Watanabe, F.S.; Dean, L.A. Estimation of Available Phosphorus in Soils by Extraction with Sodium Bicarbonate; USDA Circ. 939; USDA: Washington, DC, USA, 1954.

34. Page, A.L.; Millar, R.H.; Keeney, D.R. Methods of Soil Analysis, Part 2; American Society of Agronomy and Soil Sciences Society of America: Madison, WI, USA, 1982.

35. Spiegel, H.; Dersch, G.; Hösch, J.; Baumgarten, A. Tillage effects on soil organic carbon and nutrient availability in a long-term field experiment in Austria. Die Bodenkultur. 2007, 58, 47-58.

36. Dhamak, A.L.; Karanjikar, P.N.; Jadhav, S.B.; Ambegaonkar, P.R.; Deshmukh, R.B. Impact of tillage and organics on nutrient content and nutrient uptake of kharif sorghum. Asian J. Soil Sci. 2010, 4, 214-216.

37. Liu, Q.; Xu, H.; Mu, X.; Zhao, G.; Gao, P.; Sun, W. Effects of different fertilization regimes on crop yield and soil water use efficiency of millet and soybean. Sustainability 2020, 12, 4125. [CrossRef]

38. Mohanty, S.; Paikaray, N.K.; Rajan, A.R. Availability and uptake of phosphorus from organic manures in groundnut (Arachis hypogea L.)-corn (Zea mays L.) sequence using radio tracer technique. Geoderma 2006, 133, 225-230. [CrossRef] 
39. Ming-Gang, X.; Dong-Chu, L.; Li, J.-M.; Dao-Zhu, Q.; Yagi, K.; Hosen, Y. Effects of Organic Manure Application with Chemical Fertilizers on Nutrient Absorption and Yield of Rice in Hunan of Southern China. Agric. Sci. China 2008, 7, 1245-1252. [CrossRef]

40. Morya, J.; Tripathi, R.K.; Kumawat, N.; Singh, M.; Yadav, R.K.; Tomar, I.S.; Sahu, Y.K. Influence of Organic and Inorganic Fertilizers on Growth, Yields and Nutrient Uptake of Soybean (Glyscine max Merril L.) under Jhabua Hills. Int. J. Curr. Microbiol. App. Sci. 2018, 7, 725-730. [CrossRef]

41. Agbede, T.M.; Ojeniyi, S.O.; Awodun, M.A.; Giwa, R.; Owo, P.; State, O.; Management, P. Effect of tillage method on growth, grain yield and nutrient content of sorghum. Int. J. Sustain. Crop Prod. 2008, 3, 35-39.

42. Lenka, S.; Lenka, N.K.; Singh, A.B.; Singh, B.; Raghuwanshi, J. Global warming potential and greenhouse gas emission under different soil nutrient management practices in soybean-wheat system of central India. Environ. Sci. Pollut. Res. 2017, 24. [CrossRef]

43. Aulakh, M.S.; Garg, A.K.; Kumar, S. Impact of Integrated Nutrient, Crop Residue and Tillage Management on Soil Aggregates and Organic Matter Fractions in Semiarid Subtropical Soil under Soybean-Wheat Rotation. Am. J. Plant Sci. 2013, 4, 2148-2164. [CrossRef]

44. Feng, Y.; Ning, T.; Li, Z.; Han, B. Effects of tillage practices and rate of nitrogen fertilization on crop yield and soil carbon and nitrogen. Plant Soil 2014, 60, 100-104. [CrossRef]

45. Al-Kaisi, M.M.; Yin, X.; Licht, M.A. Soil carbon and nitrogen changes as influenced by tillage and cropping systems in some Iowa soils. Agric. Ecosyst. Environ. 2005, 105, 635-647. [CrossRef]

46. Kassam, A.; Friedrich, T. Conservation Agriculture: Principles, Sustainable Land Management and Ecosystem Services. In Proceedings of the 40th National Convention of the Italian Agronomy Society, Rome, Italy, 7-9 September 2011; pp. 7-9. Available online: https: //www.researchgate.net/profile/Theodor_Friedrich/publication/267861426_Conservation_Agriculture_ Principles_Sustainable_Land_Management_and_Ecosystem_Services/links/547f08b10cf2de80e7cc7265/ Conservation-Agriculture-Principles-Sustainable-Land-Management-and-Ecosystem-Services.pdf (accessed on 10 August 2020).

47. Kumar, V.; Kumar, M.; Singh, S.K.; Chandra, S.K. Impact of conservation agriculture on yield, nutrient uptake and quality of wheat crop in calciorthent. Plant Arch. 2015, 15, 371-376.

48. Marahatta, S.; Sah, S.K.; Macdonald, A.; Timilnisa, J.; Devkota, K.P. Influence of Conservation Agriculture Practices on Physical and Chemical Properties of Soil. Int. J. Adv. Res. 2014, 2, 43-52.

49. Sainju, U.M.; Singh, B.P.; Whitehead, W.F.; Wang, S. Accumulation and Crop Uptake of Soil Mineral Nitrogen as Influenced by Tillage, Cover Crops, and Nitrogen Fertilization. Agron. J. 2007, 99, 682-691. [CrossRef]

50. Lal, R. Carbon Sequestration in Dryland Ecosystems. Environ. Manag. 2004, 33, 528-544. [CrossRef] [PubMed]

51. Tangyuan, N.; Bin, H.; Nianyuan, J.; Shenzhong, T.; Zengjia, L. Effects of conservation tillage on soil porosity in maize-wheat cropping system. Plant Soil Environ. 2009. [CrossRef]

52. Zhu, L.; Hu, N.; Yang, M.; Zhan, X.; Zhang, Z. Effects of different tillage and straw return on soil organic carbon in a rice-wheat rotation system. PLoS ONE 2014, 9, e88900. [CrossRef]

53. Selles, F.; Kochhann, R.A.; Denardin, J.E.; Zentner, R.P.; Faganello, A. Distribution of phosphorus fractions in a Brazilian Oxisol under different tillage systems. Soil Tillage Res. 1997. [CrossRef]

54. de Sá, J.C.M.; Cerri, C.C.; Lal, R.; Dick, W.A.; de Cassia Piccolo, M.; Feigl, B.E. Soil organic carbon and fertility interactions affected by a tillage chronosequence in a Brazilian Oxisol. Soil Tillage Res. 2009. [CrossRef]

55. Rosolem, C.A.; Merlin, A. Soil phosphorus availability and soybean response to phosphorus starter fertilizer. Rev. Bras. Ciência Solo 2014, 38, 1487-1495. [CrossRef]

56. Rusu, T.; Bogdan, I.; Moraru, P.; Pop, A.; Duda, B.; Cacovean, H.; Coste, C. Tillage Effects on Soil Properties \& Respiration. EGUGA 2015, 17, 2197.

57. Vogeler, I.; Rogasik, J.; Funder, U.; Panten, K.; Schnug, E. Effect of tillage systems and P-fertilization on soil physical and chemical properties, crop yield and nutrient uptake. Soil Tillage Res. 2009, 103, 137-143. [CrossRef]

58. Bertol, I.; Engel, F.L.; Mafra, A.L.; Bertol, O.J.; Ritter, S.R. Phosphorus, potassium and organic carbon concentrations in runoff water and sediments under different soil tillage systems during soybean growth. Soil Tillage Res. 2007. [CrossRef]

59. Dorneles, E.P.; Lisboa, B.B.; Abichequer, A.D.; Bissani, C.A.; Meurer, E.J.; Vargas, L.K. Tillage, fertilization systems and chemical attributes of a Paleudult. Sci. Agric. 2015, 72, 175-186. [CrossRef] 
60. Mallarino, A.P.; Borges, R. Phosphorus and Potassium Distribution in Soil Following Long-Term Deep-Band Fertilization in Different Tillage Systems. Soil Sci. Soc. Am. J. 2006, 70, 702-707. [CrossRef]

61. Nardi, S.; Morari, F.; Berti, A.; Tosoni, M.; Giardini, L. Soil organic matter properties after 40 years of different use of organic and mineral fertilisers. Eur. J. Agron. 2004, 21, 357-367. [CrossRef]

62. Hazarika, N.; Sarmah, M.K.; Basumatary, A. Soil chemical properties as influenced by tillage and nutrient management practices after growing direct seeded sali rice. Int. J. Chem. Stud. 2018, 6, 2709-2712.

63. Tarkalson, D.D.; Hergert, G.W.; Cassman, K.G.; Tarkalson, D.D.; Hergert, G.W. Long-Term Effects of Tillage on Soil Chemical Properties and Grain Yields of a Dryland Winter Wheat-Sorghum/Corn-Fallow Rotation in the Great Plains \&quot; Long-Term Effects of Tillage on Soil Chemical Properties and Grain Yields of a Dryland Winter Wheat-Sorghum/Corn-Fallow Rotation in the Long-Term Effects of Tillage on Soil Chemical Properties and Grain Yields of a Dryland Winter Wheat-Sorghum/Corn-Fallow Rotation in the Great Plains. Agron. J. 2006, 98, 26-33.

64. Gurpreet, S. Effect of tillage practices on soil physico-chemical characteristics and wheat straw yield. Int. J. Agric. Sci. 2014, 4, 2167-2447.

(C) 2020 by the authors. Licensee MDPI, Basel, Switzerland. This article is an open access article distributed under the terms and conditions of the Creative Commons Attribution (CC BY) license (http://creativecommons.org/licenses/by/4.0/). 